\title{
Human Freedom and the Freedom of Natural Processes: On Omnicausality, A-Causality and God's Omnipotence
}

\author{
Cornel W. du Toit \\ Research Institute for Theology and Religion, University of South Africa \\ P. O. Box 392, 0003 UNISA, Republic of South Africa \\ dtoitcw@unisa.ac.za
}

\begin{abstract}
The article traces the development of causality in physical science and examines its functioning in theology, as well as its demand for a different approach to power, especially the omnipotence and omnicausality of God. The three main phases in the development of causality is briefly mentioned with special reference to some applicable notions of Hume, Newton and Kant. Some examples are given of developments that contributed to the erosion of the causality concept in the sciences during the nineteenth century. The possibility of thinking of God in a-causal terms is proposed. The idea of an omni-causal God is build upon a pre-modern monarchical view. The question whether the importance of God as an omni-causal agent forms part of our regulative thinking, is dealt with. Special attention is given to the way Karl Barth interprets our knowledge of God as well as God's power. We take the stance that the idea of God's omnipotence does not imply his omnicausality. This implies that he respect the freedom (autopoeticism) of nature as he respect the freedom of humans. This stance obviates the need to prove God as the magical force in or behind natural and physical events. The action of God is seen on the consequential side of events and not on its causal side.
\end{abstract}

Keywords

causality, demise of causality in the natural sciences, omnipotence and omnicausality of God, the a-causal God, a consequential God

\section{Introduction}

My premise is that a plausible doctrine of God (and theology as a whole) must not conflict with current scientific knowledge. It does not mean that theology should turn positivist or submit to the dictates of a closed scientific order. But it does imply a critical attitude towards metaphysical postulates framed in terms of a worldview based on limited scientific insight. Likewise it entails criticism of contemporary attempts to accommodate God's activity in scientific paradigms like quantum determinism; of unwarranted inferences from the 
orderliness and apparent planning of nature such as those of intelligent design theorists; and finally, of the anthropic principle that bases grand assumptions on the fine-tuning and balance displayed by our solar system.

It means, in fact, that theology, with due regard to its distinctive character, should be mindful of the findings of physical, cosmological, biological and other sciences without incorporating these indiscriminately. Theology will continue to speak about God in images, metaphors, anthropomorphisms and anthropopathic language. It will incorporate the influence, operation and experience of transcendence at a human, existential level. Thus the scope for experience of the deity is circumscribed by human capacity and capabilities.

The article traces the development of causality in physical science and examines its functioning in theology, as well as its demand for a different approach to power, especially the omnipotence and omnicausality of God. It also takes a critical look at the ascription of causal events to God. That requires scrutiny of the background and history of the concept of causality.

Modern theology displays a fundamental insecurity. " [Modern theology] ... lives with the uncomfortable feeling that there is something not quite right with knowledge [founded] in faith - or better, there is something wrong with it." It no longer takes God to be an object of human research and knowledge, as orthodox tradition was wont to do. Van der Kooi maintains that the traditional notion of God has changed to the extent that it can at most function as a concept or word in the language we use. ${ }^{3}$ This assigns theology the task of rethinking the doctrine of God so that it will be meaningful once more in our day. Runzo expresses a similar sentiment. ${ }^{4}$ The biblical sciences work with texts, church history with events, but (systematic) theology seeks to define truths about God: "This immediately casts a certain shadow or religious suspicion on theology." But there is no other way. Even if we premise ourselves on God's self-revelation in Scripture we cannot but reflect on it in terms of our own conceptual schemes, which in their turn are shaped by our worldview. "Human reasoning about God is an intrinsic element of the very content itself of revelation and the experience of God." 5

On the one hand we confess, following Kant, that God is unknowable or, following Barth, that he is the Totally Other (Ganz Andere). Yet it does not

\footnotetext{
1 Knowledge has become mystery. Absolute norms to appraise truth have become blurred. Unified knowledge has made way for multi-perspectivity. See also C. W. du Toit, Viewed from the Shoulders of God (Pretoria: RITR, 2007), 155 .

2 C. van der Kooi, As in a Mirror: John Calvin and Karl Barth on Knowing God (Leiden: Brill, 2005), 226.

3 Van der Kooi, As in a Mirror, 226.

4 J. Runzo, Reason, Relativism and God (Hampshire: Macmillan, 1986), 234.

5 Runzo, Reason, 235.
} 
deter theologians and metaphysicists from writing whole volumes about him. Examples will be furnished below.

God's unknowability does not mean that he cannot be experienced (via the Word, sacraments, rites, tradition), or that crucial human experiences cannot be associated with his presence and activity. But that is not the same as metaphysically construed ideas about the essence of God.

The notion of a-causal discourse on God may well be misinterpreted if it were to imply that he exercises no influence or refrains from active involvement. That is not the intention. It simply means critically evaluating causal predication to whatever agency (including transcendent forces) in light of a reappraisal of the concept of causality. It entails applying God's a-causality to nature and physical processes that are self-explanatory by virtue of their autopoietic character. The notion of a-causality affirms that God does not intervene by manipulating natural processes.

An a-causal relation between God and the natural world does not imply a new brand of deism or endorsement of Steven Gould's NOMA (non-overlapping magistrata) principle. Deism means the absence of a creator God from an autopoietic creation. Divine a-causality, on the other hand, acknowledges his involvement with the human world without disregarding the self-explanatory character of physical and other natural processes. If nature is conceived as completely divorced from God we end up with dualism. ${ }^{6}$ At most a-causality means that God allows nature to exist alongside him in freedom (and independence). He may still be an active, creative influence "behind" nature. That makes symbolic but not literal sense.

If one accepts the autopoeticism of natural processes and instead takes a look at God's influence on the believer's existential world, the inescapable question is whether it is not equally illegitimate to attribute such involvement in people's personal situations to him. After all, that involvement is not provable either. So why not repudiate divine activity in our personal lives as well? But there is a world of difference between forcibly imposing divine activity on self-explanatory natural processes and ascribing the course of events to divine intervention at the complex level of personal faith. The notion of God's consequential activity clarifies this. If we choose to believe that God accepts, forgives, loves us and arranges our lives, that belief influences our worldview and actions. It cannot be repudiated, nor does it contradict natural laws and processes.

6 Concepts like dualism and monism are metaphysically laden. Monism (also read pantheism and panentheism), on the other hand, implies that everything is God or in God. If everything is in God, does that mean that God is in everything? Surely humans are not arbiters of where God wills himself to be or not to be, to act or not to act. 


\section{Three Main Phases in the Development of the Concept of Causality}

There is no era in human history when some notion of causality did not feature. The level at which it functions has always been linked intuitively with everyday experience, tradition and popular sentiments. Things do not just happen. Gods, humans, all manner of good or evil forces are responsible for what exists and what happens. People do not examine causality scientifically. By and large complex events are simplistically ascribed to a single agency.

Hardly any scientific concept has been subject to as much change as causality. It evolved from pre-scientific animism, to Greek ontology, to Newtonian mechanistic physics, to relativity and quantum indeterminacy. Not only did new insights give rise to new conceptions of causality; they culminated in the virtual elimination of the very idea: "At the beginning there was the apparent truism that science consists in the knowledge of causes; we now end up with the paradoxical avowal that there is no place at all in the programme of science for the 'knowledge of causes'."7

We can discern three phases in scientific reflection on causality. The first was the Greek (mainly Aristotelian) era, which lasted from classical times up to the $15^{\text {th }}$ century scientific revolution, the dawn of the second era. The third was the era of modernism and quantum interpretation of reality. Obviously this trichotomy is a broad approximation and each era can be subdivided into various secondary phases.

\section{Classical (Greek) Views of Causality}

The concept of causality is discussed by Plato (429-347 B.C.E.) in his Phaedo. In this dialogue causality is clearly no longer rooted in a magical or animistic worldview. Studying nature meant looking for the causes of things: how and why did they come about and eventually vanish? Causes are classified logically: physical motion is a proximal cause governing the body's position, whereas thought, the real cause, is the remote cause of physical motion. ${ }^{8}$

\footnotetext{
7 Kotarbinski, quoted in Z. Puterman, The Concept of Causal Connection (2 vols.; Filosofika Studier 30; Uppsala: University of Uppsala, 1977), 20.

8 This view was to provoke strong opposition. Descartes could not believe that immaterial thought can move material objects. See W. Ehrenberg, Dice of the Gods (London: University of London, 1977), 4-5.
} 
Aristotle (384-322 B.C.E.) deals with causality in books II and III of his writing Physics. ${ }^{9}$ He discusses change and the reasons we adduce for it. He distinguishes between a material cause (causa materialis), the matter which constitutes something and in which it resides; a formal cause (causa formalis), the form or archetype (essence and genus); an effective cause (causa efficiens), the principal source or agency of change; and the final cause (causa finalis), the telos, purpose or reason for doing something. The causa finalis has teleological undertones and does not feature in physical science. Natural processes are blind. To Aristotle the effective cause precedes the effect. Together the four causes account for changes in nature. Aristotle assumed temporal contiguity between cause and effect. ${ }^{10}$

Whereas weather conditions were often attributed to the gods, Aristotle considered them natural. ${ }^{11}$ It rains because warm air rises (remember, every element always moves to its natural "position"), cools and is precipitated as raindrops. Natural processes have nothing to do with human weal or woe: "Similarly if a man's crop is spoiled on the threshing-floor, the rain did not fall for the sake of this - in order that the crop might be spoiled - but that result just followed... Why then should it not be the same with the parts in nature ... ?"12 Aristotle's doctrine of causality was particularly influential in the Middle Ages. It shifted changes that occur from the magical to the rational sphere. The causa formalis was no longer part of a Platonic world of ideas; it was imbedded in matter.

Aristotle identifies twelve modes of causation. An important distinction is that between actual and potential. He explains it with reference to motion: "...motion is in the movable. It is the fulfilment of this potentiality by the action of that which has the power of causing motion; and the actuality of that which has the power of causing motion is not other than the actuality of the movable; for it must be the fulfilment of both."13 The same effect can have different causes; some things cause each other reciprocally, though not in the same manner; and the same cause can have different consequences. ${ }^{14}$

He also discusses the status of chance and spontaneity. ${ }^{15}$ Some things simply happen for no apparent reason. "But chance and spontaneity are also

\footnotetext{
9 Aristotle, The Complete Works of Aristotle (Princeton: Princeton University Press, 1984), 1 : $327-356$.

10 Ehrenberg, Dice, 7 .

11 Aristotle, The Complete Works, 339.

12 Aristotle, The Complete Works, 339.

13 Aristotle, The Complete Works, 344; also see 333.

14 Aristotle, The Complete Works, 333.

15 Aristotle, The Complete Works, 334ff.
} 
reckoned among causes." ${ }^{16}$ There are innumerable reasons for chance events. ${ }^{17}$ He stresses that some things occur regularly. ${ }^{18}$ Chance and spontaneity are incidental modalities of causes rather than additional causes. Spontaneity differs from chance and is governed by deliberation. People as moral agents can will something for some reason. The difference lies in intentionality, which is evinced by human agents. ${ }^{19}$

\section{The Middle Ages}

\subsection{Boethius $(480-525)$}

Although Boethius dates to the very early Middle Ages (5th-15th century), his principal work, De consolatione philosophiae, was, after the Gospels, the most influential book during the ensuing centuries. The Consolation was probably written while he was awaiting execution (he was charged with high treason, which he denied). Boethius was not happy with Aristotle's emphasis on chance. ${ }^{20}$ In his Consolation he engages in dialogue with philosophy, personified as a woman. There is a higher power that determines and ordains everything. The Christian God leaves no loopholes, hence Aristotle's notion of chance is rejected. He elevates the cause-effect sequence to a closed network of causes, thus extending divine providence across the spectrum. "If chance is defined as an event produced by random motion without any causal nexus, I would say there is no such thing as chance. If God imposes order upon all things there is no opportunity for random events." ${ }^{21}$ Clearly this impugns human freedom, which Boethius tries to solve by invoking the mystery of time. God created the world, space and time and their state is that of God's eternal presence. "Everything that is known is comprehended not according to its own nature, but according to the ability to know of those who do the knowing."22 God knows proleptically what choices humans will make and, given this knowledge, he ordains what will happen. Thus Boethius manages to preserve both human freedom and divine omnicausality. Aristotle never linked causes in such a closed network.

\footnotetext{
16 Aristotle, The Complete Works, 334.

17 Aristotle, The Complete Works, 336.

18 Aristotle, The Complete Works, 335.

19 Aristotle, The Complete Works, 335.

20 Ehrenberg, Dice, 14.

21 Quoted in Ehrenberg, Dice, 13.

22 Quoted in Ehrenberg, Dice, 14.
} 
Medieval people were unaware of having a worldview with schematic implications for their thinking. Everything, including God's being, was taken literally as expounded. Truth claims about God were considered claims about God himself. This was because of "the absence of any notion that every human conception only derives its meaning and truth from within the strictures of an enculturated human schema". ${ }^{23}$ That awareness would only dawn with Kant.

Yet the high Middle Ages (11th-13th century) saw a change. ${ }^{24}$ In the 12 th century, under the influence of Aristotle, the world was increasingly seen as a place that is governed by laws. "In such a world, how were men to regard God's interventions by means of miracles? What sort of powers and causes formed the basis for miracles taking place?... It was assumed that created things have a receptive capacity, a potentiae oboedentialis, which made possible a reaction or response on the part of lower natural powers and causes to the higher, preternatural power of God himself." 25

\subsection{Luther (1483-1546)}

Luther was a transitional figure between the late Middle Ages and early modernity. I deal with him cursorily because of his enormous influence on Reformed theology. The issue of causality and God's omnicausality is raised in the context of the confinement of the human will, which is the title of the work that we briefly consider (De servo arbitrio). It is a diatribe against Desiderius Erasmus' treatise on free will. The premise is God's foreknowledge of what happens according to his will. "Do you suppose that He does not will what He foreknows, or that He does not foreknow what He wills? If He wills what He foreknows, His will is eternal and changeless, because His nature is so." ${ }^{26}$ A stark, metaphysical image of God as the Unmoved Mover emerges. Luther cites Boethius approvingly: "Yet the will of God, which rules over our mutable will, is changeless and sure - as Boetius [sic] sings, 'Immovable Thyself, Thou movement giv'st to all'; and our will, principally because of its corruption, can do no good

23 Runzo, Reason, 240.

24 In the $13^{\text {th }}$ century Duns Scotus $\left(1265^{-1308}\right)$ distinguished between natural, free and causal causes. Most things are determined by natural causes and are self-evident. Free causes are accompanied by a sense of making a conscious choice and they do not always have the same effect. A causal cause is a consequence of some extraordinary event such as lamb being born with two heads, cf. Ehrenberg, Dice, 15-16.

25 Van der Kooi, As in a Mirror, 180.

26 M. Luther, The Bondage of the Will (trans. J. I. Packer and O. R. Johnston; London: Clarke, 1957), 80 . 
of itself." 27 The entire work is a rhetorical exercise using biblical texts to prove the bondage of the human will (to $\sin /$ Satan). But that will is no less bound by God's foreknowledge, which in its turn is based on his will. "However, with regard to God, and in all that bears on salvation or damnation, he has no 'freewill', but is a captive, prisoner and bondslave, either to the will of God, or to the will of Satan." 28

The background to this style of reasoning is the metaphysical concept of "by grace alone" (sola gratia). Fears of the Roman Catholic notion of good works as a (subsidiary) means to salvation are taken to absurd lengths in the doctrine of the captivity of the human will. If humans could do good or believe in God of their own accord, God's salvific activity would be redundant - and that could not be countenanced! Even Genesis 4:7, where God tells Cain to master evil, is dismissed, because we in ourselves cannot master evil. "What need is there for the Spirit, or Christ, or God if 'free-will' can overcome the motions of the mind to evil?... If these words were taken indicatively, as they stand, they would be promises of God; and, since He cannot lie, the result would be that no man would sin; and then it would be needless to give men commandments."29

The intention is not to demolish the Reformed cornerstone of sola gratia. I am merely asking whether the outdated metaphysical loading of the concept has not become redundant. Luther's view remains fundamental to Reformed doctrine and forms the background to the notion of causality in Reformed churches and their resistance to scientific theses about autopoetic nature and processes governed by chance. ${ }^{30}$

\section{The Scientific Era}

The crucial change made by the 16th century scientific revolution was that it was no longer concerned about the causes of consequences but about the operation of cause and effect: what were the underlying principles?

27 Luther, The Bondage, 81.

28 Luther, The Bondage, 107.

29 Luther, The Bondage, 157.

30 Various other proposals were made to harmonise determinism and free will. One example is the 16 th century Jesuit, Luis de Molina, who tried to retain both divine providence and human free will. God foreknows human choices, consequently they accord with his intentions. He knew beforehand that Pharaoh would harden his heart and not allow the Israelites to leave Egypt. Jesus knew that Peter would deny him. God does not intervene by abolishing human free will, for it does not jeopardise his sovereignty. 


\subsection{Galileo (1564-1642)}

Galileo established classical mechanics. He rejected the Aristotelian notion that every object (body) strives and reaches for its "natural" position. ${ }^{31}$ That would mean ascribing it to some inherent force (élan vital?). Galileo also repudiated the notion that motion happens only under direct impact of a force. It is an intuitive idea that force can only be transmitted through physical contact. It was not understood that it could function at a distance (see electro-magnetism, a later discovery). This gives rise to the concept of inertia, according to which a body that is not subject to the operation or influence of some force would exist in a state of perpetual repose or motion. Hence an active force is the reason for change and motion. Descartes denied this, accepting only extension. To him even motion was fortuitous, an accident and not something substantial. ${ }^{32}$

\subsection{Hume $(1711-1776)$}

Hume's critique of naïve views of causality remained hugely influential for a long time. In his The Natural History of Religion ${ }^{33}$ he writes as follows about cause and effect: "We are placed in this world as in a great theatre, where the true springs and causes of every event are entirely concealed to us; nor have we either sufficient wisdom to foresee, or power to prevent those ills, with which we are continually threatened ... No wonder, then, that mankind, being placed in such an absolute ignorance of causes, and being so anxious concerning their future, should immediately acknowledge a dependence on invisible powers, possessed of sentiment and intelligence."

He identifies basic rules for the cause-effect relationship: temporal and spatial contiguity; cause precedes effect; a consistent link (unity) between cause and effect; the same cause always triggers the same effect; if different causes have the same effect it implies that they share a common property; if resembling causes have different effects it must attributed to specific qualities in which they differ; if any object increases (in whatever respect) with the increase of its cause, it is to be regarded as a compound effect; an object which exists for any time in its perfection without producing its effect is not the whole cause of that effect when it eventually occurs. ${ }^{34}$

\footnotetext{
31 See Aristotle, Complete Works, 355.

32 Puterman, The Concept, 112.

33 D. Hume, "The Natural History Of Religion," in Hume on Religion (ed. R. Wollheim; London: Collins, 1963), 31-99, 4off.

34 Ehrenberg, Dice, 30-31.
} 
The following quotations from his work clarify these rules. We impose a causal relation between two events because of their contiguity. "What is our idea of necessity, when we say that two objects are necessarily connected together?... I perceive, that they are contiguous in time and place, and that the object we call cause precedes the other we call effect." 35 However, "... reason alone can never give rise to any original idea, and reason as distinguish'd from experience, can never make us conclude, that a cause or productive quality is absolutely prerequisite to every beginning of existence... [S]ince reason can never give rise to the idea of efficacy, that idea must be deriv'd from experience, and from some particular instances of this efficacy, which make their passage into my mind by common channels of sensation or reflection."36

Hume held the meta-ethical view that moral judgments principally express feelings. He saw moral values as matters of social convention. Humans do not have a separate faculty of moral perception. Morals are attributable to our faculties of sensory perception. Hume sees the operation of the mind when viewing causality in nature and causality in human affairs (morality) as analogous: "We must now shew, that as the union betwixt motives and actions has the same constancy, as that in any natural operations, so its influence on the understanding is also the same, in determining us to infer the existence of one from that of another."37 Our mind cannot attribute necessity to the operations in nature and deny the same necessity in human operations: "Now moral evidence is nothing but the conclusion concerning the actions of men, deriv'd from the consideration of their motives, temper and situation." ${ }^{38}$ And in his Dialogues he writes: "What I have said concerning natural evil will apply to moral conduct, with little or no variation; and we have no more reason to infer, that the rectitude of the Supreme Being resembles human rectitude than that his benevolence resembles the human."39

The relevance of Hume's thought to our subject is the way humans observe events in physical reality, connect these events in a causal, necessary way and transpose this method of arriving at the truth to the level of human experience in general and morals in particular. We impose a causal link between a person's motive and the ensuing deed. As in the case of natural phenomena, the link between motive and deed on a moral level is established through custom

\footnotetext{
35 D. Hume, A Treatise of Human Nature (ed. P. H. Nidditch; Oxford: Clarendon, 1978), 155.

36 Hume, A Treatise, 157.

37 Hume, A Treatise, 404.

38 Hume, A Treatise, 404.

39 D. Hume, "Dialogues Concerning Natural Religion," in Hume on Religion (ed. R. Wollheim; London: Collins, 1963), 187.
} 
(the way the mind operates). ${ }^{40}$ On a religious level we ultimately attribute whatever happens to the will of God. Nothing transpires unless God wills it. Bad experiences raise the question why God willed (allowed) that to happen to me. We then come up with all sorts of motives God could have had (sin, disobedience, a test, etc.) to inflict the event on us.

\section{Force and Causality (Newton [1642-1727])}

Newton sees force as inherent (vis insita) in an entity. It is an inherent inertia, implying that an entity that is not subjected to the exercise of a force will remain in a state of either repose or perpetual motion. ${ }^{41}$ Hence to Newton inertia is a kind of "inactive" force in matter. A force acting from outside (vis impressa) can affect this and influence the entity's repose or motion. Newton also introduces the novel concept of direct interaction over distance. In this way he sought to establish motion's independence of time (i.e. simultaneity in the universe). According to Newton, absolute time exists independently of any perceiver and progresses at a consistent pace throughout the universe. Unlike relative time, Newton believed absolute time was imperceptible and could only be understood mathematically. Force in the sense of action over distance became a basic tenet of classical physics. ${ }^{42}$ That, plus external force as a cause, gave causal theory a mechanical basis. ${ }^{43}$ Physical laws in which force features were regarded as causal laws.

Equating force with cause created confusion between deterministic and causal laws. Unlike causality, determinism presupposes a closed system: in given circumstances A will always result in B. In the 19th century it was realised that force was a theoretical construct. Eliminating the passage of time shows that some interactions are deterministic rather than causal (determinism is unequivocal, whereas causality can be interpreted variously, hence is multivocal). Mechanical processes may be causally determined. However, mechanical

40 Custom is a principle of human nature. All inferences from experience are effects of custom, not of reasoning. Custom is one of the "principles of nature" which renders our experience useful to us by providing a kind of pre-established harmony between the course of nature and the succession of our ideas, cf. S. L. Altmann, Is Nature Supernatural? A Philosophical Exploration of Science and Nature (New York: Prometheus, 2002), 87,106. Custom, as used by Hume, is thus a feature of the mind, not of the community. The capacity of the mind to use causal statements correlates with physical properties that the brain acquired during the evolution of the species, according to Altmann (1978:101).

41 Puterman, The Concept, 112.

42 Puterman, The Concept, 113.

43 Puterman, The Concept, 114. 
processes cannot indicate the flow of time, for it deals exclusively with symmetrical relations in which something is either a cause or an effect. So the relation can be inverted. Flow of time is extrinsic to mechanics, but is necessary to distinguish between cause and effect. Within the flow of time completed processes are irreversible. ${ }^{44}$

\section{Kant and the Transition from Ontology of Being to Epistemological Ontology}

Kant brought about a radical paradigm shift in epistemology, metaphysics and theology. Van der Kooi ${ }^{45}$ sees him as a watershed in theology: a switch from a theocentric to an anthropocentric worldview. After him knowledge was confined to this-worldly, human phenomena. The focus shifted from the known object to the knowing subject. The accent on the nature of the knowing subject set boundaries for the study of knowable things. The knowing subject was to become a cornerstone of modernism.

Kant made knowledge an immanent matter. It has objective status that cannot exceed the limits of human faculties. Knowledge of God no longer centred on the supernatural or the preternatural (going beyond nature). ${ }^{46}$ "God himself has become the Unknown. Only his relation to the world can be spoken about, and then only in terms of a category that we ourselves employ in our relation to the world, namely causality." 47 This was a major development. Talk about God is always anthropomorphic. ${ }^{48}$ Kant distinguishes between symbolic and dogmatic anthropomorphism. Whereas the latter presumes that God, the supreme being, is knowable, symbolic anthropomorphism uses metaphors to express knowledge manifested in God's relations with the world. This is a relational analogy, differing from the analogy of being (Aquinas' analogia entis) or the analogy of faith (Barth's analogia fidei). To Kant God's relation to the world is analogous with the "relation" between a ship and its builder, a clock and a clockmaker or a general and his regiment. ${ }^{49}$ This both overlaps and differs from the proposed a-causal theology. Kant's relation, albeit analogous, still implies that objective reality is externally determined (the example of the

\footnotetext{
44 Puterman, The Concept, 115.

45 Van der Kooi, As in a Mirror, 225.

46 See van der Kooi, As in a Mirror, 225.

47 Van der Kooi, As in a Mirror, 243.

48 We cannot dispense with anthropomorphic language, even in physics. Examples of anthropomorphic scientific terms are force; energy; resistance; power; fatigue (as in metal fatigue); labour. See Puterman, The Concept, 104ff.

49 See van der Kooi, As in a Mirror, 243-244.
} 
shipbuilder and the clockmaker). It is too close to dogmatic anthropomorphism, which lands theology in deep water when it has to defend that relation on a scientific forum. The relational analogy does work when it refers to interpersonal interaction (the general and his regiment). In addition Kant remains trapped in dualism with his distinction between pure and practical reason. Practical reason and its assumptions merely establish a new brand of metaphysics.

Scientific criticism of causal theory is accommodated by my proposal of immanent transcendence. ${ }^{50}$

\section{Erosion of the Concept of Causality in the Physical Sciences in the 19th Century}

Erosion of the concept of causality was a gradual process. As in the case of evolution theory, more and more instances were added to the list of objections to the concept. The notion of causality was progressively whittled down with every new discovery in the micro-world of atoms. "The enquiry into causes had been successful everywhere and made physics and chemistry technologically productive." ${ }^{11}$ Ehrenberg cites the following examples:

- In the 19th century atomism gained fresh impetus from the calculation of Avogadro's number - the number of atoms per weight unit of matter. Early in the 19th century it was discovered that atoms can be electrically charged. By the end of the century the photo-electric effect was discovered. "But by and by in the nineteenth century cases and fields of study came under consideration in which laws and causes appeared to be replaced by randomness and chance. ${ }^{52} \mathrm{~A}$ case in point was research into gases. The numbers of molecules and atoms involved were so great that they could only be approximated as means of random events. Thus the mean speed of molecules, determined by the temperature of the gas, their weight and size were sufficient to arrive at a kinetic theory of gases, which eventually found a place in statistical mechanics. ${ }^{53}$

- Radioactivity further supported the role of chance. In 1903 Crookes, Elster and Geitel discovered that scintillations (caused by alpha particles, being positively loaded helium atoms) appear on a fluorescent screen located close to a radium source. This was the first observation in history of an

50 C. W. du Toit, "Shifting Frontiers of Transcendence in Theology, Philosophy and Science," HvTSt 67, no. 1 (2011): Art. \#879, 10 pages. DOI: 10.4102/hts.v67i1.879. Cited 9 May 2013. Online: http://www.hts.org.za/index.php/HTS/article/view/879.

51 Ehrenberg, Dice, $5^{2}$.

52 Ehrenberg, Dice, 53 .

53 Ehrenberg, Dice, 54 . 
effect produced by an individual atom. It enabled them to establish that radiation is not a continuous process. "No causal explanation was ever found which explained the instant of transmutation." 54

- Schrödinger (1887-1961) established wave mechanics. ${ }^{55}$ From this he inferred that the motion of particles was not governed by laws. "The motion of particles conforms to the laws of probability but the probability itself is propagated in accordance with the laws of causality." 56

- Heisenberg and quantum theory: again the role of chance overshadowed necessity. This was a radical departure from classical physics, which saw causality and space-time as one. In quantum theory they are complementary and mutually exclusive. ${ }^{57}$

In 1927 Eddington declared that physics could no longer endorse a scheme of deterministic laws. "Science thereby withdraws its moral opposition to free will." 58

The question is: in how far does the end of causality in the physical sciences suggest an a-causal approach for theology? Also, is it necessary, maybe even inescapable? That applies to both the doctrine of God and the concept of personhood.

\section{An A-Causal Doctrine of God?}

Since the genesis of human thought the deity was used as an explanatory concept to fathom reality. The need to understand and explain is still with us, but it has come to mean something else. To medieval man the existence and omnicausal activity of God were unquestionably assured, while the natural world was mysterious and uncertain. Today the positions are reversed. The operation of natural processes is fairly firmly established, but the existence and character of God are uncertain. Van der Kooi confirms this: "That which is evident no longer lies above man, but below him."59

Because science offers convincing grounds for grasping and explaining the physical world (creation), and because that conflicts with the notion that selfexplanatory processes are actually controlled by God, we must ask why the idea of an all-governing, all-powerful God is forced upon levels of understanding

\footnotetext{
54 Ehrenberg, Dice, 55 .

55 Puterman, The Concept, 63 .

56 Puterman, The Concept, 64.

57 Puterman, The Concept, 66.

58 Ehrenberg, Dice, 68.

59 Van der Kooi, As in a Mirror, 226.
} 
where it is not needed. What we can understand is no longer supernatural, mysterious or transcendent.

\subsection{God the Monarch of Premodernism}

McFague points out that biblical language about God was governed by the worldview of that age and its historically determined image of God the king. ${ }^{60}$ This led to a monarchic doctrine of God, whose hallmarks were absolute power and sovereignty. That doctrine has become obsolete. "It supports conceiving of God as a being existing somewhere apart from the world and ruling it externally either directly through divine intervention or indirectly through controlling the wills of his subjects ... This picture, while simplistic and anachronistic, continues in spite of its limitations, because of its psychological power: it makes us feel good about God and about ourselves. It inspires strong emotions of awe, gratitude, and trust toward God and, in ourselves, engenders a satisfying swing from abject guilt to joyous relief. Its very power is part of its danger, and any picture that seeks to replace it must reckon with its attraction." ${ }^{\prime \prime}$

Talking about God in such terms is passé, besides contradicting the idea that God can be grasped by human intelligence. "In short, is the value of accommodated language not undermined by God's majesty, precisely because He is not swallowed up in his accommodation?"62 Calvin uses the image of a mother speaking to her child in baby-talk. But that is in fact the point: the baby has grown up, is an adult (Bonhoeffer) and we no longer need baby-talk. That was part of the uninformed worldview of yore.

Otto Weber renounces the notion of God's absolute power (potentia absoluta). His omnipotence is divine precisely because he relinquished it. ${ }^{63} \mathrm{His}$ power and his will are inseparable, implying that any arbitrary exercise of power is tempered by his will, the will of the covenant, so his history is not conceivable without the human race. But Weber is no less insistent that divine power is not confined to what is humanly possible. God can do the impossible, like becoming human, vanquishing death, justifying the ungodly. ${ }^{64}$ There are

\footnotetext{
60 S. McFague, Models of God: Theology for an Ecological, Nuclear Age (Philadelphia. Fortress, 1987), 63 ff.

61 McFague, Models, 64-65.

62 Van der Kooi, As in a Mirror, 185; see also 186.

63 O. Weber, Grundlagen der Dogmatik (Göttingen: Neukirchener Verlag, 1972), 1: 486. In his own words: "Wir sind, indem wir seiner Allmacht preisgegeben sind, in Wahrheit ihm als dem Allmächtigen preisgeben," see Weber, Grundlagen, 487. This may sound paradoxical but underscores the notion of "taming" metaphysical concepts by linking them to human existence. Thus God's omnipotence is relinquished because we are consigned to it.

64 Weber, Grundlagen, 487.
} 
various objections to the traditional Reformed doctrine of God. It is based on outdated metaphysical systems and falls back on the Greek notion of an unmoved mover. The same may be said of the traditional proofs of God's existence (cf. Aquinas). The doctrine of an all-powerful, all-governing God is an embarrassment to theology in light of present-day cosmological, physical and biological insight into autopoietic processes. Then why does power remain so dominant in reflections on God? Surely we have moved beyond the do ut des idea, whereby we have to bargain with an all-governing God, bribing him to do humankind some miraculous favour. That culminates in the theodicy problem which, despite all manner of metaphysical constructs devised by theologians, cannot be adequately resolved. It also leads to a tug of war between determinism and human freedom, which likewise remains inconclusive. It operates with the problematic doctrines of predestination and election, which in their turn require metaphysical constructs to counter the arguments against them (cf. Barth's solution). It conflicts with the idea of a personal God who relates to humans. And it does not accord with more spontaneous, anthropomorphic language about God.

The classical Reformed doctrine of God (exemplified by Calvin) takes divine omnipotence for granted. God's power (potentia) includes the right and authority (potestas) to exercise it. ${ }^{65}$ This links up with the notion of the unmoved mover without whom nothing can exist or happen. The divine attributes omnipotence, omniscience, omnipresence and the like - are inevitably metaphysical concepts with little more than symbolic value, for nobody can grasp what something like omnipotence or omniscience really means (finitum non capax infiniti).

\subsection{Shift of Focus from Ontological Reality to Thinking Subject}

Kant focuses on human cognitive ability and the structures of human reason. Part of the regulative function of human reason, according to him, is the fact that we not only think about things we cannot know, but are also incapable of not thinking about them. "In thinking itself, he says, there is the tendency to go beyond all experience, namely the unconditioned in things in themselves, or

\footnotetext{
65 K. Barth, The Doctrine of God (vol. II/1 of Church Dogmatics; Edinburgh: T \& T Clark, 1957), 526 puts it thus: "Like all true might, it is in itself and from the beginning legitimate power, the power of the holiness, righteousness, and wisdom which is grounded in itself, in the love and freedom of the divine person... What God is able to do de facto, He is also able to do de jure." God's power stems from his ownership of his creation. As the potter (Jer 18:6; Rom 9:20) he has a claim to the clay that belongs to him. Many other texts are cited to make this point, see Luther, The Bondage, 526 .
} 
in a series of conditions 'which reason, by necessity and by right, demands in things in themselves, as required to complete the series of conditions'." 66 Hence the regulative principle of reason requires a kind of rational wholeness, which includes the metaphysically oriented aspects of human thought: “... reason has the inclination to venture to the farthest bounds of knowledge and to seek for a unity in which it can find rest". ${ }^{67}$ It is reminiscent of Augustine's restless heart that can only find peace in God. ${ }^{68}$ The problem is that this creates new aporias: "As soon as one begins to regard this regulative or Unbedingte as an object that man can know, as constitutive principle about which men can form a concept, one falls into antinomies. The regulative idea is not an object that can be defined by thought; it is nothing more than a necessary framework that makes thinking in its unity possible." 69 Theological examples of this regulative idea include the oneness of the trinity, divine attributes like omniscience, omnipotence, omnipresence, immutability, et cetera. They are purely regulative, for we do not know what omnipotence, omniscience, omnipresence and the like really mean. The exception is analogies, which we can imagine and which feature in experience of God via prayer, worship and human experience. These are images of God as a father, mother, friend, judge, teacher or whatever. That is where an a-causal theology puts the accent.

\subsection{Barth}

Berkhof ${ }^{70}$ points out that 19th century theology (under the influence of German idealism with its focus on the subject) marks a radical departure from the metaphysical doctrine of God of earlier centuries by proposing what is known as mediation theology (Vermittlungstheologie). God's transcendence is inseparable from his condescension (condescendentie), that is his incarnation. ${ }^{71}$

Karl Barth refused to venture into the field of any kind of natural theology or theology of nature. That accounts for his otherwise inexplicable antipathy to the physical sciences (which he assigned at best a niche "at God's left hand").

\footnotetext{
66 Van der Kooi, As in a Mirror, 242.

67 Van der Kooi, As in a Mirror, 242. Also see W. Pannenberg, Metaphysics and the Idea of God (Edinburgh: T \& T Clark, 1988), 22ff.

68 In their design of a neuro-theology D'Aquili and Newberg also identify "properties" of the human brain that are necessary to make sense of the world. One of these is the need for explanation and the unity of everything (see Eugene G. d'Aquili and Andrew B. Newberg, The Mystical Mind: Probing the Biology of Religious Experience (Minneapolis, Minn.: Fortress, 1999).

69 Van der Kooi, As in a Mirror, 242.

70 H. Berkhof, Christelijk geloof (Nijkerk: Callenbach, 1973), 116.

71 This is akin to the notion of immanent transcendence: transcendence only makes experiential sense in terms of immanent reality, see Du Toit, "Shifting Frontiers."
} 
Did he sense that any theological attempt to explain God's role in the operation of natural processes would do the God concept a disfavour? Rather keep quiet about any supposed divine control of nature! Although Barth eschews interaction with the sciences, nature (God's creation), God's ownership of creation and his omni-governance and omnicausality in natural processes feature throughout his theology.

But does a contemporary God concept require metaphysical constructs of divine attributes? Failure to speak of God's role in self-explanatory physical processes does not diminish his sovereignty. Divine involvement makes sense at the level of interpersonal relations where existential human problems are experienced acutely. That is where human religious experience affirms God's role as reconciler, comforter, friend, succour, et cetera.

But do totally incomprehensible metaphysical processes become intelligible if we link them with very concrete personal, social or historical concepts? If we "domesticate" metaphysical or radically transcendent concepts (either by way of the Thomist analogy of being or the Barthian analogy of faith), are we not erasing the difference between divine and human reality? What are we saying when we talk about God's caring omnipotence? It sheds no light on the metaphysical concept of omnipotence, for that we can never fathom. It does add a depth (transcendent) dimension to the concept of care: we can understand concepts like love, forgiveness, mercy, compassion, reconciliation, pity. But then these concepts acquire a depth dimension which nowadays might be termed miraculous when they refer to God's involvement with human beings. In some human situations mercy, forgiveness, compassion are simply unthinkable. When - counter to all expectation - they are manifested and God's hand is read into what happens, it is experienced as miraculous, and so ordinary human events acquire a transcendent dimension. That is the approach I espouse, which I call immanent transcendence. ${ }^{72}$

A hallmark of God's (metaphysical) attributes is that they invariably comprise twin concepts: a metaphysical term linked with a familiar human quality. In this way God's power is linked with his care. Because God is responsible for everything and has to care for it, he surely needs to have the ability (power) to do so. But Barth's strategy in this respect is misleading. Linking a familiar quality like goodness, love, care or faithfulness with an unknowable metaphysical concept does not make the latter knowable. Omniscience, omnipotence,

\footnotetext{
72 Transcendence only makes experiential sense in terms of immanent reality, see Du Toit, "Shifting Frontiers."
} 
infinitude and the like are not qualities humans can know. They may be metaphysically "necessary", but remain unknowable none the less. ${ }^{73}$

Hence to Barth abstract discussion of God's omnipotence is taboo: "God's might is not a concept which can be derived from cosmology, from the hierarchic design of a closed universe. The orientation has shifted to the history of Jesus Christ as the crossing point where all lines come together and, above all, proceed from." ${ }^{74}$ But even a Christ-centred theology is not immune to this criticism. Certainly we cannot expunge concepts of infinitude from metaphysics or even from everyday language. We unavoidably deal with ideas like infinity and human reason dwells on the unthinkable. But that does not mean that we have clarified or fathomed the meaning of these words. As a rule they function symbolically at most.

God can take care of his creation, Van der Kooi ${ }^{75}$ avers, because he is mighty. From this he rightly concludes: "In contemporary theology such a prominent position for the concept of might would be unthinkable. Might stands for the power to make decisions regarding control, and therefore a God who has power can hardly be exempted from responsibility for excesses or atrocities and suffering." Nonetheless he proceeds to justify Barth's use of the term.

God's omnipotence relates directly to his omnicausality (omni-governance). Barth does not specify what he means by omnicausality, but he is unmistakably speaking of univocal or linear causality. The distinctions identified in the scientific evolution of the term are not mentioned, neither would Barth have acknowledged them, for that would embroil him in natural theology.

Barth is even reluctant to reflect logically on the notion of omnipotence, evidenced by his condemnation of Aquinas' attempts to do so. ${ }^{76}$ Aquinas maintained that, whatever its object, divine omnipotence had to be absolutely possible, hence compatible with the concept of being. "Whatever comes under the concept of its opposite, non-being, is as such absolutely impossible, and therefore cannot form the object of divine omnipotence."77 It is impossible for the almighty to act in a self-contradictory way or to do inherently contradictory things in the creaturely world, such as turning a person into an animal, constructing a triangle whose three angles do not equal two right angles or a circle whose radius differs from place to place - hence any logical inconsistency. Barth half-heartedly concedes the point, then states: "We cannot accept

\footnotetext{
73 By contrast the earthiness of revelation proposed by Berkhof, Christelijk geloof, $53-55$ is more appealing.

74 Van der Kooi, As in a Mirror, 354.

75 Van der Kooi, As in a Mirror, 354.

76 Barth, The Doctrine, II/1: 534 .

77 Barth, The Doctrine, II/1: 534.
} 
the idea of an absolutely possible or impossible by which even God's omnipotence is to be measured. On the contrary, we have to recognise that God's omnipotence is the substance of what is possible. Necessarily, then, we dispute the reasons offered by Thomas and his followers for rejecting the statement that even what is to be described as absurd in creation is the object of God's omnipotence."78

I shall not dwell on Barth's attempts to relate God's omnipotence and omnicausality to the theodicy problem and the fall. Suffice to say that he adopts the aforementioned strategy of linking these problems with known, even pathosfilled terms, which fails to resolve the actual problems. The doctrine that God shares in human suffering (theopaschitism, the suffering God) does not explain why an almighty and loving God permits that suffering in the first place.

\section{Does God's Omnipotence Imply Omnicausality?}

Weber points out that Reformed theology sought to assign the human, creaturely will some autonomy, however marginal. In that case God would not be the author of evil/sin (auctor mali/peccati). ${ }^{79}$ After all, it would add nothing to his glory to be worshipped by mindless automatons. Neither could he have a genuine relationship with humans unless they were free.

To Weber, then, God's omnipotence does not imply omnicausality - hence the heading Allmacht, nicht Allkausalität. ${ }^{80}$ In fact, the very problem that God, being almighty, is responsible for human sin or the existence of injustice, suffering and misfortune stems from the notion that he is omnicausal (causa causarum). ${ }^{81}$ Weber sees God and reality as two unequal parts of the same great ontological whole. It does not mean that God has to be slotted into every facet of ontological (also read physical) reality. That fact that he is the symbolic ground of all that exists does not make him part of that existence. Weber then makes a case - and here I fully concur - for the autonomy, and distinctive nature of the creaturely world. ${ }^{82}$ He substantiates this by seeing the causa

\footnotetext{
78 Barth, The Doctrine, II/1: 534 .

79 Weber, Grundlagen, 489.

80 Weber, Grundlagen, 490.

81 Weber, Grundlagen, 490, puts it thus: "Der Gott, von dem in der eben umrissenen Problematik die Rede war, ist in seiner potentia, voluntas und letzlich in seiner scientia die causa causarum."

82 "Ist es dann verwunderlich, dass auch die andere, die kreatürliche Seite in all ihrer Bedingtheit doch zugleich eben als diese andere Seite gleichsam ihr Recht fordert?" see Weber, Grundlagen, 490.
} 
causarum as a short cut to deism and pantheism. ${ }^{83}$ If God determines everything, everything is God (pantheism); if he has programmed all reality, his presence is no longer required (deism).

\subsection{Free Nature?}

To my mind the notion of an autopoietic natural world may be regarded as analogous with human freedom vis-à-vis God. If God grants humans some freedom and autonomy, why should that be impossible in the case of physical natural processes? It made sense to see him as the creator and sustainer of nature and its processes when we were ignorant of their functioning. But science has now disclosed these and pinpointed their autopoieticism. We also realise that they do not operate in accordance with our notion of causality. Hence the only interpretation that makes sense is that natural processes are free from constant divine intervention. That also absolves theology from the need to make God the omni-expositor of self-explanatory processes. Of course nature is not free in the same way as humans are. Freedom in the evolution of physical and natural processes is evident in the role of chance in the emergence of new entities. Here the possibility of successful mutations could culminate in better adapted species. This freedom, then, depends on chance, so nature's freedom vis-à-vis God lies in the fact that its laws and processes follow their own course without arbitrary divine intervention. Besides, it is not so easy to manipulate complex systems, as new insight into the role of causality showed.

Other explanations that account for events in mystical terms or ascribe them to God's inscrutable will get us no further.

Dingemans, ${ }^{84}$ too, affirms that God and nature are not the same. Natural disasters must not be identified with or attributed to God. Famine and disease are not sent directly by him. In worldly events God is the conditional rather than the executive power. ${ }^{85}$ The conditional aspect should be interpreted purely symbolically. Explaining in how far God is the condition for all that exists is physically impossible, so the notion is symbolic.

We should approach it even more radically. Humans are involved in a threefold relationship: with God, with the world and with themselves (coram Deo, coram mundo, coram me ipso). But in his relationship with humans God confronts the inexplicable mystery of reality along with humans and in dialogue

83 Weber, Grundlagen, 490.

84 Dingemans, De stem van de roepende (Kampen: Kok, 2000), 127.

85 Dingemans, De stem van de roepende, 159. 
with them. Incarnation means that God shares our being-in-the-world and our exposure to immanence with its tragedy and rewards. God, our friend, does not travel the road by our side knowing in advance what hardships we will have to endure (and moreover preordaining these!), only to comfort us after the event for consequences he could have prevented. As our travelling companion he himself is caught by surprise when unforeseen events come our way and he influences our handling of misfortunes so that, with hindsight, we can say (sometimes - not always) that everything turned out for the best; that there was joy in that grief; that grace still triumphed; that the experience of his nearness and love supported us. Such interpretations add a transcendent dimension to life - one that enables us to get back on our feet against all odds and carry on in spite of what befell us.

The reason for citing these excerpts from theological reflection on divine omnipotence was to illustrate that they function at most symbolically and do not really add to our knowledge of God's nature. The concept of omnipotence has been used since the dawn of time because of an intuitive sense that power must be one, that one supreme power causes everything.

\section{God the Consequence}

The term consequence can also be interpreted causally. ${ }^{86}$ God does not necessarily cause a situation, but humans freely turn to him in moments of existential crisis. Hence his role in my life is not that of a causer of all that happens, but of one who contemplates the consequences of events along with me and helps me find the most appropriate response. The accent is not on God as the underlying source of misfortune but on God who involves himself with the believer in order to make the best of things. It is when people have to endure poverty, injustice, exploitation, sickness or misfortune that calling on God may be their sole option. The response never takes the form of a miracle, but in retrospect the person who invoked God's aid interprets the outcome as grace. Outsiders may see this as subjective projection, but for those who have been through the mill it is their experience of transcendence.

\footnotetext{
86 The term "consequence" also occurs in John Cobb Junior's design of his process theology. It is akin to the approach I outline. Cobb does not see God as the creator of the world. His nature is consequent, which refers to the manner of his presence in our world, see Dingemans, De stem van de roepende, 129.
} 


\section{Résumé}

I have provided some excerpts from the history of the concept of causality. What emerges is that criticism of this concept in scientific circles, as well as that of philosophers and some theologians, still has to be digested theologically. Theology is not a copycat of the sciences, but neither can it stubbornly hold on to ideas that are no longer plausible. The progressive eradication of naive conceptions of causality in the sciences and their replacement with new models (like emergence) can have fruitful parallels in theology. What I propose is to legitimise theology's position in its confrontation with the sciences by acknowledging that God respects the freedom (read autopoieticsm) of nature no less than the freedom of human beings. That does not deprive him of his sphere of influence, as is evident in religious experience. While that sphere cannot be demonstrated directly at the level of nature, it could still function symbolically. That is expressed by the concept of God as a consequence.

\section{Bibliography}

Aristotle. The Complete Works of Aristotle: Revised Oxford Translation. 2 Vols. Edited by J. Barnes. Princeton: Princeton University Press, 1984.

Altmann, S. L. Is Nature Supernatural? A Philosophical Exploration of Science and Nature. New York: Prometheus, 2002.

Barth, K. The Doctrine of God. Vol. II/1 of Church Dogmatics. Edinburgh: T \& T Clark, 1957.

Berkhof, H. Christlijk geloof. Nijkerk: Callenbach, 1973.

D'Aquili, E. G. and A. B. Newberg. The Mystical Mind:Probing The Biology OfReligious Experience. Minneapolis, Minn.: Fortress, 1999.

Dingemans, G. D. J. De stem van de roepende. Kampen: Kok, 2000.

Du Toit, C. W. "Shifting Frontiers of Transcendence in Theology, Philosophy And Science." HvTSt 67, no. 1 (2011): Art. \#879, 10 pages. DOI: 10.4102/hts.v67i1.879. Cited 9 May 2013. Online: http://www.hts.org.za/index.php/HTS/article/view/879.

- "Some Barthian Perspectives on the Present Science-Religion Debate: What Is the Place of 'Natural Theology' Today?" HvTSt 63, no. 4 (2007): 1447-1471. . Viewed from the Shoulders of God. Pretoria: RITR, 2007.

Ehrenberg, W. Dice of the Gods. London: University of London, 1977.

Hume, D. A Treatise Of Human Nature. Edited by P. H. Nidditch. Oxford: Clarendon, 1978.

. "Dialogues concerning Natural Religion." Pages 99-204 in Hume on Religion. Edited by R. Wollheim. London: Collins, 1963.

. "The Natural History of Religions." Pages 31-99 in Hume on Religion. Edited by R. Wollheim. London: Collins, 1963.

Ladyman, J. "Does Physics Answer Metaphysical Questions?" Pages 179-201 in Philosophy of Science. Edited by A. O' Hear. Cambridge: Cambridge University Press, 2007.

Lewis, M. Altering Fate: Why the Past Does Not Predict the Future. New York: Guilford, 1997.

Luther, M. The Bondage of the Will. Translated by J. I. Packer and O. R. Johnston. London: Clarke, 1957 . 
McFague, S. Models of God: Theology for an Ecological, Nuclear Age. Philadelphia: Fortress, 1987. Pannenberg, W. Metaphysics and the Idea of God. Edinburgh: T \& T Clark, 1988.

Puterman, Z. M. The Concept of Causal Connection. 2 Vols. Filosofika Studier 3o. Uppsala: University of Uppsala, 1977.

Runzo, J. Reason, Relativism and God. Hampshire: Macmillan, 1986.

Van der Kooi, C. As in a Mirror: John Calvin and Karl Barth on Knowing God. Leiden: Brill, 2005.

Weber, O. Grundlagen der Dogmatik. Göttingen: Neukirchener Verlag, 1972. 